MEDIKA ALKHAIRAAT : JURNAL PENELITIAN KEDOKTERAN DAN KESEHATAN 1(2): 74-81

e-ISSN: 2656-7822, p-ISSN: 2657-179X

\title{
GAMBARAN PENDERITA EKLAMPSIA YANG DIRAWAT DI ICU RSU ANUTAPURA DAN RSUD UNDATA PALU PERIODE TAHUN 2015 - 2017
}

\author{
Nazlah Nirmalasari $^{1}$ Faridnan $^{1}$ dan Salmah Suciaty $^{1^{*}}$ \\ ${ }^{1}$ Program Studi Pendidikan Dokter, Fakultas Kedokteran Universitas Alkhairat, Jl. Diponegoro No. 39 Palu \\ 94221, Sulawesi Tengah, Indonesia \\ *Corresponding author: Telp: +628114536960, email: salmah.suciaty@yahoo.co.id
}

\begin{abstract}
ABSTRAK
Eklampsia merupakan masalah kesehatan dunia, Indonesia, Sulawesi Tengah, bahkan Kota Palu di mana merupakan faktor yang mendominasi penyebab langsung kematian pada ibu, sehingga harus dirawat secara intensif di ruang ICU. Eklampsia merupakan kasus akut pada penderita preeklampsia, yang disertai dengan kejang menyeluruh dan koma. Jadi, dengan mengetahui gambaran penderita eklampsia dapat dijadikan sebagai bahan promosi kesehatan dalam rangka menanggani, mengurangi kasus, dan dampak dari eklampsia.Tujuan penelitian adalah untuk mengetahui gambaran penderita eklampsia yang dirawat di ICU RSU Anutapura dan RSUD Undata Palu Periode Tahun 2015 - 2017. Metode penelitian yang digunakan adalah metode deskriptif terhadap 31 buah rekam medik penderita eklampsia dari RSU Anutapura dan RSUD Undata Palu periode tahun 2015 - 2017. Data diperoleh melalui rekam medik penderita dan hasilnya diisi pada lembar formulir penelitian. Di lakukan analisis distribusi frekuensi menggunakan program perangkat lunak SPSS 24.0. Hasil penelitian menunjukkan (1) Gambaran penderita eklampsia berdasarkan umur ibu terbanyak adalah pada umur 20 - 35 tahun $(77,4 \%)$ dan umur ibu $>35$ tahun $(22,6 \%)$. (2) Gambaran penderita eklampsia berdasarkan riwayat kehamilan terbanyak pada primigravida $(51,6 \%)$ dan multigravida $(48,4 \%)$. (3) Gambaran penderita eklampsia berdasarkan riwayat hipertensi terbanyak pada penderita yang mengalami hipertensi sebelum kehamilan $(54,8 \%)$ dan penderita yang mengalami hipertensi selama kehamilan (45,2\%). (4) Gambaran penderita eklampsia berdasarkan pemberian obat-obatan terbanyak pada pemberian $\mathrm{MgSO}_{4}(90,3 \%)$ dan pemberian diazepam (9,7\%). (5) Gambaran penderita eklampsia berdasarkan jenis eklampsia terbanyak pada eklampsia intrapartum (41,9\%), eklampsia antepartum (32,3\%), dan eklampsia postpartum (25,8\%). Disimpulkan bahwa penderita eklampsia yang dirawat di ICU RSU Anutapura dan RSUD Undata Palu sebagian besar berumur 20 - 35 tahun, primigravida, mempunyai riwayat hipertensi, kebanyakan terjadi saat intrapartum, dan terbanyak diberikan $\mathrm{MgSO}_{4}$.
\end{abstract}

Kata Kunci: Eklampsia, Kehamilan, ICU

\section{ABSTRACT}

Eclampsia is a world health problem. Indonesia, Central Sulawesi, and even Palu City which is a factor that dominates the direct cause of death in mothers, so it must be treated intensively in the ICU. Eclampsia is an acute case in patients with preeclampsia, which is accompanied by generalized seizures and coma. So, by knowing the description of eclampsia sufferers can be used as a health promotion material in order to handle, reduce the cases, and the impact of eclampsia. This study aim to find out the description of eclampsia patients treated in ICU Anutapura and Undata Hospital Palu in the period of 2015 - 2017. The research method used is descriptive method of 31 medical records of eclampsia patients from Anutapura and Undata Hospital, Palu in period of 2015 - 2017. Data was obtained through medical records of patients and the results were filled out on the research form sheet. Frequency analysis was analyzed using SPSS 24.0 software program. The results showed (1) the most common eclampsia patients based on maternal age were 20-35 years $(77.4 \%)$ and maternal age> 35 years (22.6\%). (2) description of eclampsia patients based on 
the history of pregnancy most in primigravida (51.6\%) and multigravida (48.4\%). (3) The description of eclampsia patients based on history of hypertension is most in patients who have hypertension before pregnancy (54.8\%) and patients who have hypertension during pregnancy (45.2\%). (4) The description of eclampsia patients is based on the administration of most drugs in the administration of $\mathrm{MgSO}_{4}$ (90.3\%) and administration of diazepam (9.7\%). (5) The most common eclampsia based on eclampsia is intrapartum eclampsia (41.9\%), antepartum eclampsia (32.3\%), and postpartum eclampsia (25.8\%). It was concluded that eclampsia patients treated at ICU Anutapura and Undata Hospital Palu were mostly 20 - 35 years old, primigravida, had a history of hypertension, mostly occurred during intrapartum, and most were given $\mathrm{MgSO}_{4}$.

Keywords: Eclampsia, Pregnancy, ICU

\section{PENDAHULUAN}

Eklampsia merupakan kasus akut pada penderita preeklampsia disertai kejang menyeluruh pada ibu, dengan atau tanpa penurunan kesadaran (gangguan SSP), yang berhubungan dengan tanda-tanda dan gejala dari preeklampsia seperti hipertensi, proteinuria, peningkatan kadar enzim hati, dan lain-lain. Sama halnya dengan preeklampsia, eklampsia dapat timbul pada antepartum, intrapartum, dan postpartum. ${ }^{1,3,4}$

Di Amerika Serikat dilaporkan bahwa kejadian eklampsia sebesar sekitar 1 dalam 3.250 kasus (Obstetri Williams. 2014). Di Inggris, insiden ini sekitar 1 dalam 2.000 kelahiran (ACOG. 2013). Di negara maju, insiden eklampsia sekitar 1 dalam 2.000 kelahiran. Kurang lebih terjadi sebanyak 2-3 kasus yang terjadi selama kehamilan baik antepartum maupun intrapartum. 1,2,5

Insiden eklampsia di Indonesia sekitar 310\% kasus (WHO. 2011). Menurut data dari Dinas Kesehatan Provinsi Sulawesi Tengah, jumlah penderita eklampsia pada tahun 2014 sebanyak 21 orang. Pada tahun 2015, sebanyak 18 kasus. Tahun 2016, total penderita eklampsia sebanyak 26 kasus. Di tahun 2017, terjadi peningkatan angka kejadian penderita eklampsia dari tahun sebelumnya dengan total penderita 30 orang. ${ }^{6,8}$

Menurut Dinkes Kota Palu tahun 2014, eklampsia merupakan salah satu yang mendominasi faktor penyebab langsung kematian pada ibu, yaitu sebesar $24 \%$. Di tahun 2015, penderita eklampsia didapatkan sebesar 17 kasus. Di tahun 2016, penderita eklampsia didapatkan sebesar 26 kasus. Pada tahun 2017, kejadian eklampsia didapatkan sebesar 23 kasus. ${ }^{7,8}$

Insidensi penderita eklampsia yang ditemukan di RSUD Undata Palu didapatkan pada tahun 2014 dan 2015 sebesar 8 kasus, sedangkan pada tahun 2016 dan 2017 mengalami peningkatan angka kejadian sebesar 11 dan 12 kasus. Angka kejadian eklampsia di RSU Anutapura Palu pada tahun 2014 didapatkan sebesar 3 kasus. Pada tahun 2015, didapatkan sebesar 10 kasus. Untuk tahun 2016, jumlah penderita eklampsia di RSU Anutapura Palu didapatkan 11 kasus. Untuk tahun 2017, jumlah penderita eklampsia di RSU Anutapura Palu, didapatkan sebesar 3 kasus. ${ }^{9,10}$

Insidensi penderita eklampsia untuk tiap negara berbeda-beda dimana lebih banyak ditemukan di negara berkembang daripada di negara maju karena banyak faktor yang memengaruhinya seperti paritas, gravida, obesitas, faktor genetik, ras, etnis, geografi, dan faktor lingkungan. Peningkatan kejadian eklampsia dapat juga disebabkan oleh karena adanya hipertensi kronik yang tidak terdiagnosa dengan superimposed preeclampsia on chronic hypertension pada perempuan yang lebih tua. ${ }^{4,}$ 11,12

\section{METODE PENELITIAN}

Desain penlitian ini adalah deskriptif dengan menggunakan pendekatan potong lintang (cross sectional). Penelitian deskriptif ini bertujuan untuk memperoleh penjelasan tentang distribusi dari gambaran usia ibu, usia kehamilan, riwayat kehamilan, riwayat 
hipertensi, riwayat asuhan antenatal (ANC), dan pemberian obat-obatan dimana subyeknya terdiagnosis menderita eklampsia yang dirawat di ICU RSU Anutapura dan RSUD Undata Palu Periode Tahun 2015 - 2017.

\section{Besar Sampel}

Penelitian ini menggunakan "Nonprobability Sampling" dengan teknik pengambilan sampel yaitu sampling jenuh.

\section{Teknik Pengambilan Sampel}

Teknik pengambilan sampel pada penelitian ini adalah menggunakan sampling jenuh dimana semua penderita yang telah terdiagnosa eklampsia dan memenuhi kriteria penelitian yang tercatat dalam rekam medis di RSU Anutapura dan RSUD Undata Palu periode tahun 2015 - 2017 dijadikan sebagai sampel penelitian.

\section{Prosedur Penelitian}

Pada setiap data ibu hamil yang didiagnosa mengalami eklampsia di ICU RSU Anutapura dan RSUD Undata Palu akan:

1) Peneliti meminta izin kepada institusi atau direktur rumah sakit dalam hal ini RSU Anutapura dan RSUD Undata Palu untuk melihat data penderita eklampsia dan tenaga medis yang menangani ibu hamil dan melahirkan sebagai populasi penelitian.

2) Setelah izin diberikan oleh pimpinan atau direktur rumah sakit untuk pengambilan data sekunder penderita eklampsia, peneliti akan mengambil data sekunder penderita eklampsia tersebut di bagian Rekam Medik RSU Anutapura dan RSUD Undata Palu.

3) Kemudian peniliti akan mengumpulkan semua data sekunder yang telah diperoleh dari bagian Rekam Medik RSU Anutapura dan RSUD Undata Palu.
4) Semua data yang telah terkumpul akan diinput ke dalam komputer dalam tabel untuk analisa deskriptif.

5) Selanjutnya akan dilakukan pengolahan dan analisis data lebih lanjut dengan mengunakan program SPSS 24.0. Data yang ada akan sangat dijaga kerahasiaannya dengan memakai nomor kode mengunci semua data di komputer.

6) Setelah analisis data selesai, peneliti melakukan penulisan hasil untuk selanjutnya diseminarkan ada seminar hasil dan disajikan secara tertulis dalam bentuk skripsi.

\section{Pengolahan dan Analisa Data}

Data pada penelitian ini diolah menggunakan perangkat lunak komputer program SPSS 24.0. Adapun analisis statistik yang digunakan adalah dekskriptif kategorik dengan melakukan perhitungan statistik sederhana. Untuk skala nominal dapat dihitung frekuensi dan persentase atau rate. Hasilnya berupa frekuensi dan persentasi yang disajikan dalam bentuk tabel.

\section{HASIL DAN PEMBAHASAN} HASIL

Penelitian ini dilakukan di RSU Anutapura dan RSUD Undata Palu pada bulan Juli 2018. Data penderita eklampsia yang didapatkan dari Bagian Rekam Medik RSU Anutapura dan RSUD Undata Palu yang memenuhi kriteria penelitian sebanyak 31 data responden. Pengumpulan data penelitian ini dilakukan dengan pengambilan data responden menggunakan rekam medik penderita. Adapun data yang diperoleh terdiri dari gambaran (usia ibu, riwayat kehamilan, riwayat hipertensi, pemberian obat-obatan, dan jenis eklampsia) pada penderita eklampsia. Hasil analisa statistik ditampilkan dengan sistematika sebagai berikut. 
MEDIKA ALKHAIRAAT : JURNAL PENELITIAN KEDOKTERAN DAN KESEHATAN 1(2): 74-81

e-ISSN: 2656-7822, p-ISSN: 2657-179X

a. Gambaran Penderita Eklampsia Berdasarkan Umur Ibu

Gambaran penderita eklampsia berdasarkan umur ibu dapat dilihat pada tabel 1 berikut ini.

Tabel 1. Distribusi Penderita Eklampsia Berdasarkan Umur Ibu di ICU RSU Anutapura dan RSUD Undata Palu.

\begin{tabular}{ccc}
\hline Umur Ibu & $\mathrm{N}$ & $\%$ \\
\hline - Beresiko (<20 dan >35 Tahun) & 8 & 25,8 \\
- Tidak Beresiko (20 - 35 Tahun) & 23 & 74,2 \\
\hline Total & 31 & 100 \\
\hline
\end{tabular}

Berdasarkan tabel di atas, hasil dari 31 penderita eklampsia yang dirawat di ICU RSU Anutapura dan RSUD Undata Palu yang diambil dari data rekam medik penderita serta memenuhi kriteria penelitian adalah sebagian besar pada penderita dengan umur ibu 20 - 35 tahun (tidak beresiko) yaitu sebanyak 74,2\%, dan terendah pada penderita dengan umur ibu $<20$ dan $>35$ tahun (beresiko) yaitu sebanyak $25,8 \%$.

\section{b. Gambaran Penderita Eklampsia Berdasarkan Riwayat Kehamilan}

Gambaran penderita eklampsia berdasarkan riwayat kehamilan dapat dilihat pada tabel 10 berikut ini.

Tabel 2. Distribusi Penderita Eklampsia Berdasarkan Riwayat Kehamilan di ICU RSU Anutapura dan RSUD Undata Palu.

\begin{tabular}{ccc}
\hline $\begin{array}{c}\text { Riwayat } \\
\text { Kehamilan }\end{array}$ & $\mathrm{N}$ & $\%$ \\
\hline - Primigravida & 16 & 51,6 \\
- Multigravida & 15 & 48,4 \\
\hline Total & 31 & 100 \\
\hline
\end{tabular}

Berdasarkan tabel di atas, hasil dari 31 penderita eklampsia yang dirawat di ICU RSU Anutapura dan RSUD Undata Palu yang diambil dari data rekam medik penderita serta memenuhi kriteria penelitian adalah sebagian besar pada penderita dengan primigravida yaitu sebanyak 51,6\%, dan sebagian kecil pada penderita dengan multigravida yaitu sebanyak $48,4 \%$.

c. Gambaran Penderita Eklampsia Berdasarkan Riwayat Hipertensi Sebelum Kehamilan

Gambaran penderita eklampsia berdasarkan riwayat hipertensi dapat dilihat pada tabel 3 berikut ini.

Tabel 3. Distribusi Penderita Eklampsia Berdasarkan Riwayat Hipertensi di ICU RSU Anutapura dan RSUD Undata Palu.

\begin{tabular}{lcc}
\hline $\begin{array}{l}\text { Riwayat Hipertensi } \\
\text { Sebelum Kehamilan }\end{array}$ & $\mathrm{N}$ & $\%$ \\
\hline - Ada & 17 & 54.8 \\
- Tidak Ada & 14 & 45.2 \\
\hline \multicolumn{1}{c}{ Total } & 31 & 100 \\
\hline
\end{tabular}

Berdasarkan tabel di atas, hasil dari 31 penderita eklampsia yang dirawat di ICU RSU Anutapura dan RSUD Undata Palu yang diambil dari data rekam medik penderita serta memenuhi kriteria penelitian adalah sebagian besar pada penderita dengan riwayat hipertensi sebelum kehamilan (hipertensi kronis) adalah sebanyak 54,8\%, dan sebagian kecil pada penderita dengan tidak ada riwayat hipertensi sebelum kehamilan adalah sebanyak 45,2\%.

\section{d. Gambaran Penderita Eklampsia Berdasarkan Pemberian Obat-Obatan \\ Gambaran penderita eklampsia} berdasarkan pemberian obat-obatan dapat dilihat pada tabel 4 berikut ini.

Tabel 4. Distribusi Penderita Eklampsia Berdasarkan Pemberian Obat-Obatan di ICU RSU Anutapura dan RSUD Undata Palu.

\begin{tabular}{lcc}
\hline Pemberian Obat-Obatan & $\mathrm{N}$ & $\%$ \\
\hline - Pemberian $\mathrm{MgSO}_{4}$ & 28 & 90,3 \\
- Pemberian Diazepam & 3 & 9,7 \\
- Pemberian Phenytoin & 0 & 0 \\
\hline Total & 31 & 100 \\
\hline
\end{tabular}


Berdasarkan tabel di atas, hasil dari 31 penderita eklampsia yang dirawat di ICU RSU Anutapura dan RSUD Undata Palu yang diambil dari data rekam medik penderita serta memenuhi kriteria penelitian adalah sebagian besar pada penderita yang diberikan $\mathrm{MgSO}_{4}$ adalah sebanyak $90,3 \%$, dan hanya sebagian kecil pada penderita yang diberikan diazepam adalah sebanyak 9,7\% sedangkan tidak terdapat penderita dengan pemberian phenytoin yaitu $0 \%$.

\section{e. Gambaran Penderita Eklampsia Berdasarkan Kejadian Eklampsia}

Gambaran penderita eklampsia berdasarkan kejadian eklampsia dapat dilihat pada tabel 5 berikut ini.

Tabel 5. Distribusi Penderita Eklampsia Berdasarkan Kejadian Eklampsia di ICU RSU Anutapura dan RSUD Undata Palu.

\begin{tabular}{ccc}
\hline Kejadian Eklampsia & $\mathrm{N}$ & $\%$ \\
\hline - Eklampsia Antepartum & 10 & 32,3 \\
- Eklampsia Intrapartum & 13 & 41,9 \\
- Eklampsia Postpartum & 8 & 25,8 \\
\hline Total & 31 & 100 \\
\hline
\end{tabular}

Berdasarkan tabel di atas, hasil dari 31 penderita eklampsia yang dirawat di ICU RSU Anutapura dan RSUD Undata Palu yang diambil dari data rekam medik penderita serta memenuhi kriteria penelitian adalah sebagian besar pada penderita dengan eklampsia intrapartum adalah sebanyak $41,9 \%$, penderita dengan eklampsia antepartum adalah sebanyak $32,3 \%$, dan sebagian kecil terdapat pada penderita dengan eklampsia postpartum adalah sebanyak $25,8 \%$.

\section{PEMBAHASAN}

\section{a. Gambaran Penderita Eklampsia Berdasarkan Umur Ibu}

Dari hasil penelitian gambaran penderita eklampsia yang dirawat di ICU RSU Anutapura dan RSUD Undata Palu berdasarkan umur ibu didapatkan sebagian besar pada penderita dengan usia $20-35$ tahun sebanyak 77,4\%, hal ini sejalan dengan penelitian yang dilakukan oleh Lisa Kusumawati (2013) di RSUD Dokter Soedarso Pontianak yang mengatakan bahwa penderita eklampsia sebagian besar pada umur 20 - 35 tahun (tidak beresiko) yaitu $78,1 \%$. Hasil penelitian ini juga tidak jauh berbeda dengan penelitian yang dilakukan oleh Oktaria Denantika dkk (2015) di RSUP Dr. M. Djamil Padang yang mengatakan bahwa penderita eklampsia sebagian besar pada kelompok usia 20 - 35 tahun yaitu $61,7 \%$. Hasil penelitian ini juga sejalan dengan penelitian yang dilakukan sebelumnya oleh Siqbal Karta Asmana dkk (2016) di RS Achmad Mochtar Bukittinggi yang mengatakan bahwa angka kejadian eklampsia sebagian besar pada umur ibu 20 35 tahun sebesar 59,26\%.

Berdasarkan teori, umur ibu sangat berpengaruh terhadap kejadian eklampsia karena ketika umur ibu <20 tahun cenderung mengalami eklampsia karena belum matangnya alat reproduksi untuk hamil (ukuran uterus belum mencapai ukuran yang normal untuk kehamilan) menyebabkan adanya perubahan patologis yang dapat merugikan kesehatan ibu maupun perkembangan dan pertumbuhan janin, sedangkan pada umur >35 tahun organ reproduksi wanita mengalami penurunan fungsinya seiring peningkatan usia, akan terjadi juga proses degenaratif yang meningkatkan resiko hipertensi kronis dan wanita dengan resiko hipertensi kronik ini akan memiliki resiko yang lebih besar untuk mengalami eklampsia. $^{1,16,17}$

Usia reproduktif dari seorang wanita adalah $20-35$ tahun. Usia reproduktif ini merupakan periode yang paling aman untuk hamil dan melahirkan karena pada usia tersebut resiko terjadinya komplikasi selama kehamilan lebih rendah. ${ }^{3}$

Akan tetapi, pada penelitian ini menunjukan bahwa penderita eklampsia yang dirawat di ICU RSU Anutapura dan RSUD Undata Palu lebih banyak ditemukan pada umur 20 - 35 tahun (tidak beresiko). Berdasarkan hasil diskusi dengan pembimbing, hal ini menunjukkan 
MEDIKA ALKHAIRAAT : JURNAL PENELITIAN KEDOKTERAN DAN KESEHATAN 1(2): 74-81

e-ISSN: 2656-7822, p-ISSN: 2657-179X

bahwa penderita eklampsia yang dirawat di ICU RSU Anutapura dan RSUD Undata Palu saat hamil lebih banyak pada umur 20-35 tahun karena pada umur tersebut merupakan reproduksi yang sehat untuk kehamilan dan lebih banyak kehamilan saat terjadi di umur tersebut.

\section{b. Gambaran Penderita Eklampsia Berdasarkan Riwayat Kehamilan}

Dari hasil penelitian gambaran penderita eklampsia yang dirawat di ICU RSU Anutapura dan RSUD Undata Palu berdasarkan riwayat kehamilan didapatkan sebagian besar pada ibu dengan kehamilan primigravida yaitu sebanyak $51,6 \%$. Hal ini sejalan dengan penelitian yang dilakukan sebelumnya oleh Lisa Kusumawati (2013) di RSUD Dokter Soedarso Pontianak yang mengatakan bahwa penderita eklampsia sebagian besar pada primigravida, yaitu sebanyak 54,3\%. Hasil penelitian ini juga tidak jauh berbeda dengan penelitian yang dilakukan oleh Meita Hipson (2016) di RS Muhammadiyah Palembang yang mengatakan bahwa penderita eklampsia sebagian besar pada primigravida yaitu sebanyak $62,4 \% .{ }^{13,18}$

Berdasarkan teori primigravida mempunyai resiko lebih besar terjadinya eklampsia dibandingkan dengan multigravida. Hal ini dikarenakan eklampsia biasanya timbul pada wanita yang pertama kali terpapar vilus korion. Hal ini terjadi karena pada wanita tersebut mekanisme imunologik pembentukan blocking antibody yang dilakukan oleh HLA-G (human leukocyte antigen $\mathrm{G}$ ) terhadap antigen plasenta belum terbentuk secara sempurna, sehingga proses implantasi trofoblas ke jaringan desidual ibu menjadi terganggu. Primigravida juga rentan mengalami stres dalam menghadapi persalinan yang akan menstimulasi tubuh untuk mengeluarkan kortisol. Efek kortisol adalah meningkatkan respon simpatis, sehingga curah jantung dan tekanan darah juga akan meningkat sehingga memicu terjadinya preeklampsia berat yang disertai dengan kejang dan koma menyeluruh atau eklampsia.

\section{c. Gambaran Penderita Eklampsia Berdasarkan Riwayat Hipertensi Sebelum Kehamilan}

Dari hasil penelitian gambaran penderita eklampsia yang dirawat di ICU RSU Anutapura dan RSUD Undata Palu berdasarkan riwayat kehamilan didapatkan sebagian besar pada penderita dengan riwayat hipertensi sebelum kehamilan (hipertensi kronis), yaitu sebanyak $54,8 \%$. Hal ini sejalan dengan penelitian yang dilakukan oleh Mardiana dkk (2014) di RSUD Kabupaten Brebes yang mengatakan bahwa penderita eklampsia dengan riwayat hipertensi sebelum kehamilan adalah sebanyak 70,47\%. Hasil penelitian ini juga tidak jauh berbeda dengan penelitian sebelumnya yang dilakukan oleh oleh Nurulia Muthi dkk (2015) di RS Dr. M. Djamil Padang yang mengatakan bahwa penderita eklampsia dengan hipertensi sebelum kehamilan adalah sebanyak $85,2 \%{ }^{21,22}$

Berdasarkan teori, riwayat hipertensi sebelum kehamilan ialah bila didapatkan hipertensi yang telah timbul sebelum kehamilan atau timbul hipertensi $<20$ minggu umur kehamilan. Hipertensi sebelum kehamilan juga berpengaruh dalam terjadinya eklampsia karena pada ibu yang mengalami peningkatan usia, yaitu di atas 35 tahun akan terjadi proses degeneratif yang memperlihatkan peningkatan resiko hipertensi kronik, sehingga memiliki resiko yang lebih besar untuk mengalami eklampsia. ${ }^{23,24}$

\section{d. Gambaran Penderita Eklampsia Berdasarkan Pemberian Obat-Obatan \\ Dari hasil penelitian gambaran penderita} eklampsia yang dirawat di ICU RSU Anutapura dan RSUD Undata Palu berdasarkan pemberian obat-obatan didapatkan bahwa sebagian besar penderita eklampsia yang dirawat dberikan $\mathrm{MgSO}_{4}$ sebagai penatalaksanaannya adalah sebanyak $90,3 \%$. Hasil penelitian ini sejalan dengan penelitian yang dilakukan oleh Ekechi Okoreke dkk (2012) di Kano State, Northern Nigeria yang mengatakan bahwa penderita eklampsia yang sebagian besar mendapat pemberian $\mathrm{MgSO}_{4}$ adalah sebanyak $62,0 \%$. 
Hasil penelitian ini tidak jauh berbeda dengan penelitian sebelumnya yang dilakukan oleh Tahmina Hz dkk (2014) di District Hospital Bangladesh yang mengatakan bahwa penderita eklampsia dengan pemberian $\mathrm{MgSO}_{4}$, yaitu sebanyak $54,0 \%$. ${ }^{25,26}$

Berdasarkan teori, $\mathrm{MgSO} 4$ telah terbukti menjadi pilihan pengobatan yang efektif untuk pencegahan eklampsia. Magnesium sulfat menghambat atau menurunkan kadar asetilkolin pada rangsangan serat saraf dengan menghambat transmisi neuromuskular. Transmisi neuromuskular membutuhkan kalsium pada sinaps. Pada pemberian magnesium sulfat, magnesium akan menggeser kalsium, sehingga aliran rangsangan tidak terjadi (terjadi kompetitif inhibition antara ion kalsium dan ion magnesium). Sehingga sampai saat ini MgSO4 tetap menjadi pilihan pertama untuk antikejang pada eklampsia. ${ }^{23,27}$

\section{e. Gambaran Penderita Eklampsia Berdasarkan Kejadian Eklampsia}

Dari hasil penelitian gambaran penderita eklampsia yang dirawat di ICU RSU Anutapura dan RSUD Undata Palu berdasarkan kejadian eklampsia didapatkan bahwa sebgaian besar penderita eklampsia yang dirawat mengalami eklampsia intrapartum, yaitu sebanyak $41,9 \%$. Hasil penelitian ini sejalan dengan penelitian yang dilakukan oleh Yifru Berhan dkk (2015) di Ethiopia yang mengatakan bahwa penderita eklampsia dengan eklampsia intrapartum adalah sebesar $47,0 \%$. Hasil penelitian ini juga tidak jauh berbeda dengan penelitian yang dilakukan oleh Tahmina Hz dkk (2014) di District Hospital Bangladesh yang mengatakan bahwa penderita eklampsia dengan eklampsia intrapartum adalah sebesar $82,0 \%{ }^{8,10}$

Berdasarkan teori, eklampsia intrapartum adalah eklampsia yang ditandai dengan terjadinya kejang tonik-klonik pada ibu hamil yang tidak disebabkan oleh epilepsi atau gangguan konvulsif lainnya selama persalinan atau pada kehamilan aterm (> 37 minggu). Eklampsia intraprtum umumnya didapatkan pada wanita yang berusia relatif muda, di mana mayoritas adalah ibu dengan kehamilan primigravida, memiliki riwayat hipertensi dan disertai dengan proteinuria. ${ }^{3,29}$

\section{DAFTAR PUSTAKA}

1. Cunningham F. Gary. Hipertensi dalam Kehamilan. Obstetri Williams; Vol. 2. Ed. 23. Mc Graw Hill. 2014. P. 740 - 786.

2. The American College of Obstetricians and Gynecologists. 2013. Hypertension in Pregnancy

3. Sarwono Prawirohardjo. 2014. Hipertensi dalam Kehamilan. Ilmu Kandungan. Ed. 3. PT. Bina Pustaka Sarwono Prawirohardjo.

4. Price Sylvia A, Wilson Lorraine M. 2014. Gangguan Kejang. Patofisiologi Konsep Klinis Proses-Proses Penyakit; Vol. 2. Ed. 6. Penerbit Buku Kedokteran EGC.

5. Am J Obstet Gynecol. 2011. Circulating Angiogenic and Anti Angiogenic Factors in Pregnant Women with Eclampsia.

6. World Health Organization. 2011. Prevention and Treatment of Preeclampsia and Eclampsia.

7. Dinas Kesehatan Kota Palu. 2014. Angka Kematian Ibu. Profil Kesehatan Kota Palu Tahun 2014. P. 29-31.

8. Dinas Kesehatan Kota Palu. 2018. Angka Kejadian Eklampsia di Kota Palu Tahun $2014-2017$.

9. RSU Anutapura Palu, 2017. Angka Kejadian Eklampsia yang Dirawat di ICU RSU Anutapura Palu Tahun 2014 - 2017.

10. RSUD Undata Palu, 2017. Angka Kejadian Eklampsia yang Dirawat di ICU RSUD Undata Palu Tahun 2014 - 2017.

11. Department of Obstetrics and Gynaecology. 2012. Preeclampsia and Eclampsia.

12. Giardano Juliana G, Parpinelli Marry A, et. al. 2014. The Burden of Eclampsia: Results from A Multicenter Study on Surveillance of Severe Maternal Morbidity in Brazil.

13. Kusumawati Lisa. Hubungan Antara Preeklampsia/Eklampsia dengan Kejadian 
MEDIKA ALKHAIRAAT : JURNAL PENELITIAN KEDOKTERAN DAN KESEHATAN 1(2): 74-81

e-ISSN: 2656-7822, p-ISSN: 2657-179X

Berat Badan Lahir Rendah (BBLR) Di RSUD Dokter Soedarso Pontianak Tahun 2012. In: Fakultas Kedokteran Universitas Tanjungpura. 2013: P. 5 - 8.

14. Asmana Siqbal Karta, Syahredi, Hilbertina. Hubungan Usia dan Paritas dengan Kejadian Preeklampsia dan Eklampsia di Rumah Sakit Achmad Mochtar Bukittinggi Tahun 2012 - 2013. In: Jurnal Kesehatan Andalas. 2016. P. $642-645$.

15. Denantika Oktaria, Serudji Joserizal, Revilla Gusti. Hubungan Status Gravida dan Usia Ibu terhadap Kejadian Preeklampsia di RSUP Dr. M. Djamil Padang Tahun 2012-2013. In: Jurnal Kesehatan Andalas. 2015. P. 213 - 216.

16. The Journal of Obstetrics and Gynecology of India. 2014. Preeclampsia and Eclampsia.

17. Ludmir, Dr. Eclampsia. In: Medscape; 2017

18. Hipson Meita. Hubungan Antara Umur, Paritas Dan Pendidikan Ibu Dengan Kejadian Eklampsia Di Rumah Sakit Muhammadiyah Palembang. In: Rakernas Aipkema 2016: P. 231 - 234.

19. Urquia ML, Glazier RH et.al. 2014. Disparities in Preeclampsia and Eclampsia among Immigrant Women Giving Birth in Six Industrialised Countries.

20. Gafur Abdul, Nurdi Armyn, Ramadhany Sri, dan Rahim Muh. Rum. 2012. Hubungan Antara Primigravida Dengan Preeklampsia dan Eklampsia.

21. Karima Nurulia Muthi, Machmud Rizanda, dan Yusrawati. 2015. Hubungan Faktor Risiko dengan Kejadian Preeklampsia Berat dan Eklampsia di RSUP Dr. M. Djamil Padang.

22. Saraswati Nuning, Mardiana. Faktor Risiko Yang Berhubungan Dengan Kejadian Preeklampsia Pada Ibu Hamil (Studi Kasus Di RSUD Kabupaten Brebes Tahun 2014). In: Unnes Journal Of Public Health. 2016: P. 93 - 94.
23. Magee Laura A, Pels Anouk et.al. 2014. Diagnosis, Evaluation, and Management of The Hypertensive Disorders of Pregnancy: Executive Summary.

24. World Health Organization. 2013. Prevention and Treatment of Preeclampsia and Eclampsia: Implications and Actions.

25. Hz Tahmina. Ar Shahid, Au Hosna, and A. Alam. 2014. Study on Outcome of Eclampsia Patients in District Hospital in Bangladesh.

26. Okoreke et.al. BMC Research Notes. 2012. Benefits of Using Magnesium Sulphate $\left(\mathrm{MgSO}_{4}\right)$ for Eclampsia Management and Maternal Mortality Reduction: Lesson from Kano State in Northern Nigeria.

27. X Liu, Y Ruan, Y Liu, W Zhang. 2015. Relationship Between Maternal Age and Hypertensive Disorders in Pregnancy.

28. Berhan Yifru, Endeshaw Gezahegn. 2013. Clinical and Biomarker Difference in Prepartum and Postpartum Eclampsia.

29. Schenone Mauro H, Miller Dorothy, Samson Jacques E, and Mari Giancarlo. 2013. Eclampsia Characterisitcs and Outcomes: A Comparison of Two Eras. 